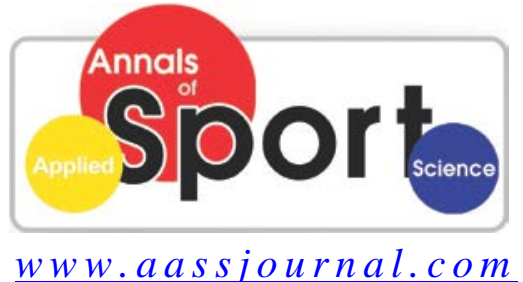

ISSN (Online): $2322-4479$

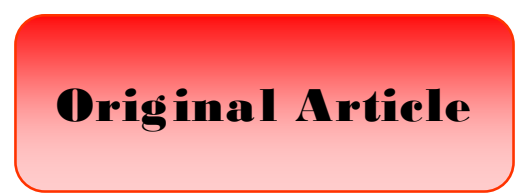

Received: 01/10/2014

Accepted: 04/01/2015

\title{
Relationship between Bone Mineral Density and Physical Activity Level in the Elderly
}

\section{${ }^{1}$ Ali Monemi Amiri, ${ }^{2}$ Seyed Reza Hosseini ${ }^{*}{ }^{3}$ Farhad Rahmaninia, ${ }^{4}$ Hajighorban Nooreddini, ${ }^{2}$ Ali Bijani}

1. Department of Physical Education and Sport Science, Guilan Science and Research Branch, Islamic Azad University, Rasht, Iran.

2. Department of Community Medicine, Social Determinants of Health Research Centre, Babol University of Medical Sciences, Babol, Iran.

3. Faculty of Physical Education and Sports Science, University of Guilan, Guilan, Iran.

4. Department of Radiology, Babol University of Medical Sciences, Babol, Iran.

\section{ABSTRACT}

This study purposed to investigate the relationship between physical activity level and bone mineral density (BMD) in the elderly of Amirkola in northern Iran. This cross-sectional study was part of a proposal to assess the situation of the elderly in Amirkola (AHAP) (Amirkola Health and Ageing Project) conducted on 1113 elderly individuals (616 males and 497 females) in Amirkola city. Physical activity was measured using a standard questionnaire of physical activity in the elderly (Physical Activity Scale for Elderly). Mineral bone mass was measured using dual energy X-ray absorptiometry in the femur neck and lumbar spines, and vitamin D levels were measured in morning blood samples. T-test, ANOVA, Pearson correlation, and linear regression tests were used to analyze data. The mean physical activity of women (118.6 \pm 55.5$)$ was higher than that of men (110.3 \pm 71.1$)(\mathrm{p}=0.035)$. This study found a significant positive relationship between total physical activity and femur bone mineral density $(\mathrm{p}=0.001$ and $\mathrm{r}=0.101)$, but this association was not significant in lumbar spines ( $\mathrm{p}=0.597$ and $\mathrm{r}=0.016$ ), though bone mineral density increased in both areas with increased physical activity ( $\mathrm{p}=0.098)$. A significant inverse relationship between age and physical activity $(p=0.001)$ and between age and bone mineral density $(p=0.001)$ was observed. Analyzing the influencing variables using the linear regression model indicated physical activity, age, and BMI had significant relationships with bone mineral density in the femur, but neither vitamin D nor calcium played a role. Given the positive correlation between bone mineral density and physical activity, it can be concluded that low intensity weight-bearing activities carried out in compliance with safety rules may be suitable for the elderly. Key Words: Osteoporosis, Osteopenia, Femur Neck, Lumbar Spine.

Corresponding Author:

Seyed Reza Hosseini

E-mail: hosseinim46@yahoo.com 


\section{INTRODUCTION}

In 2005, the elderly population of the world was reported to be 650 million people; this figure is projected to reach 2 billion by the year 2050. In Iran, the proportion of the elderly population is also increasing because of a decline in the birth rate and access to better health care; this ratio was approximately $7.3 \%$ in 2005 and is predicted to reach $11.6 \%$ in 2025 and $30.6 \%$ in 2050 (1). As the elderly population increases, the prevalence of chronic and noncommunicable diseases, such as cardiovascular diseases, diabetes, hypertension, and osteoporosis, increases (1). Osteoporosis is the most common metabolic bone disease, starting with a decrease in bone mass and degeneration of bone tissue, which consequently cause thinning of bones that makes them prone to fractures (2). Bone fractures, the most common clinical symptom of this disease in the elderly, impose high treatment and health care costs on society. It is estimated that medical costs related to this disease in the United States was nearly \$ 17 billion in 2005 (3-5). Several factors effective in osteoporosis have been identified, the most important of which include genetics, nutrition, internal hormones, and lack of exercise (6-8). According to estimates, the prevalence of this disease in the world will increase incredibly by the year 2050 due to population aging and undesirable changes in lifestyle and diet (9). In Iran, the national program of prevention, diagnosis, and treatment of osteoporosis has revealed that more than $70 \%$ of women and $50 \%$ of men over the age of 50 years suffer from either osteoporosis or osteopenia (9). Complications may begin from childhood in cases of poor nutrition and lack of physical activity that prevent sufficient bone mineral deposits. Almost $10 \%$ of the maximum bone mass decreases up to 80 years and $20 \%$ up to 65 years. The rate of bone loss is higher in women: almost $20 \%$ of bone mass is lost up to 65 years of age and $30 \%$ up to 80 years. After 50 years, men's bone mass decreases about $1 \%$ per year. While bone loss starts from the third decade of life (after menopause), as the rate of bone loss will be between $2 \%$ and $3 \%$ per year (10). Exercise is essential for proper bone growth. Although exercise has only a minor effect or none at all on bone length, it does increase bone width and density through higher mineral deposits in the bone's matrix, which increases bone strength (11). Sports strengthen the skeleton through gravitation or muscle tension forces that generate tension in the skeleton. If the tension is higher than optimal traction, osteogenesis is present. Reliable evidence indicates that weight-bearing exercises play a critical role in increasing peak bone mass during adolescence and provide mechanical stimuli or important pressure to maintain bone health and minimize bone loss (12-14). It is noteworthy that regular exercise helps the body slow the rate of bone aging. Regardless of age, people who have an active lifestyle have incredibly higher bone density than disabled people their own age. Exercise can provide healthy and prepared stimuli to maintain and even increase bone density in adults (15). Given the few studies conducted on physical activity levels and bone mineral density in Iranian elderly, this study aimed to determine the association between physical activity level and bone mineral density in people older than 60 years in Amirkola.

\section{MATERIALS AND METHODS}

This study is part of a cohort study on the health status of the elderly in Amirkola (AHAP, number 892917) begun in 2010 on all persons older than 60 years of age in Amirkola in northern Iran (16).

Participants. Through letters and phone calls, all elderly citizens were provided the 
necessary information about the project and invited to participate. Of the total 2234 elderly living in Amirkola, 1616 entered the study. Among those, 1113 had sufficient information to enter the study, and the rest were excluded as they did not refer for BMD nor had incomplete data.

Data Collection. Data on physical activity was measured using a standard questionnaire of physical activity in the elderly (PASE) and was collected through interviews $(17,18)$. The validity and reliability of this questionnaire (Cronbach's alpha coefficients of 0.97) were evaluated in an Iranian study (19). The questionnaire used in this study had three parts. The first part consisted of six questions concerning leisure-time physical activities; the second part asked three questions related to housework activities; and the third part concerned job-related activities. Based on the scoring method, the score of each activity was multiplied in its distribution and scores were added up. Then the total physical activity score for each individual was calculated as between 0 and 400; higher scores meant higher physical activity levels.

Bone mineral mass (BMD) was measured in the left femur neck and lumbar spines (L2L4) by dual energy X-ray absorptiometry (DEXA) using the Lexxos densitometer 2008 (made in France), and individuals were classified according to the World Health Organization based on T-Score into one of the following groups: T-Score $<-2.5 \mathrm{SD}$ as osteoporosis, $-2.5<$ T-Score $<-1$ osteopenia, and T-Score $>-1$ normal $(20,21)$. A morning blood sample was taken from all participants, and serum levels of $25(\mathrm{OH})$ vitamin $\mathrm{D}$, the active form of this vitamin, were measured by ELISA (enzyme-linked immunosorbent assay) in the Cellular and Molecular Research Center of Babol University of Medical Science, Babol, Iran. A measurement of less than 20 nanograms per milliliter (50 nmol per liter) was considered as lacking vitamin $\mathrm{D}$, between 20-29.99 nanograms per milliliter was considered an insufficient level, and values equal to or greater than 30 nanograms per milliliter were considered as adequate vitamin levels (22). Blood calcium was measured using the test Pars-Azmoon kit.

Statistical Analysis. SPSS 18 statistical software and t-tests, ANOVA, Pearson correlation, and linear regression were used to analyze quantitative variables, and the chisquare test was used for qualitative variables. P-values less than 0.05 were considered significant.

\section{RESULTS}

Of the 1113 elderly participants in this study, 616 were male (55.3\%) and 497 female (44.7\%); mean age of participants was $68.3 \pm$ 6.9 years (range $=60-92$ years), and mean body mass index (BMI), which was higher among women than men $(\mathrm{p}=0.001)$, was 27.3 \pm 4.6. Furthermore, the mean bone mineral mass of the lumbar and femural areas were higher in men than in women (Table 1).

No significant differences were observed in the various physical activities (PASE Score) in elderly men and women. Women were more active during their leisure-time, housework, and total physical activities, while men were only more active in job-related physical activities (Table 2).

Table 3 shows the results of ANOVA of bone mineral density and the various factors affecting it. In the current study, 221 patients (166 men and 55 women) had normal bone mineral density, 505 individuals (350 males and 155 females) were osteopenic, and 387 patients (100 males and 287 females) had osteoporosis. As can be seen in this table, jobrelated $(\mathrm{P}=0.013)$ and housework physical activity had significant relationships with bone mineral density $(\mathrm{P}=0.014)$, but these relationships were not significant in leisuretime and total physical activity $(\mathrm{P}=0.093)$. Nevertheless, bone mineral density was decreased by a decline in physical activity, and patients with osteoporosis had lower levels of 
physical activity than patients in the other groups.

Table 1. Mean \pm SD of age, anthropometric indices, and bone mineral mass in terms of gender in the elderly of

Amirkola in 2010-2011

\begin{tabular}{cccccc}
\hline Variables & Male & Female & Total & Maximum & Minimum \\
\hline Age & $68.3 \pm 7.1$ & $67.7 \pm 6.6$ & $68.3 \pm 6.9$ & 92 & 60 \\
\hline Height & $162.8 \pm 6.3$ & $151.4 \pm 6.2$ & $157.7 \pm 8.4$ & 181.5 & 130 \\
\hline Weight & $69.7 \pm 12.7$ & $65.9 \pm 12.5$ & $68 \pm 12.8$ & 117 & 40 \\
\hline BMI & $26.2 \pm 4.16$ & $\wedge 28.6 \pm 4.8$ & $27.3 \pm 4.6$ & 43.2 & 13.9 \\
\hline Femur neck circumference & $39.13 \pm 4$ & $35.6 \pm 4.6$ & $37.5 \pm 4.4$ & 108 & 32 \\
\hline Lumbar circumference & $95.5 \pm 10.5$ & $96.3 \pm 12.3$ & $95.9 \pm 11.4$ & 128 & 85 \\
\hline BMD of femur & $0.89 \pm 0.15$ & $0.78 \pm 0.14$ & $0.84 \pm 0.15$ & 1.4 & 0.38 \\
\hline BMD of L2-L4 & $0.93 \pm 0.18$ & $0.78 \pm 0.16$ & $0.86 \pm 0.18$ & 1.7 & 0.39 \\
\hline
\end{tabular}

Table 2. Mean \pm SD of different physical activities (PASE Score) according to gender among the elderly in Amirkola in 2010-2011

\begin{tabular}{lcccc}
\hline \multicolumn{1}{c}{ Variable } & $\begin{array}{c}\text { Total mean and SD } \\
\text { of PASE }\end{array}$ & $\begin{array}{c}\text { Mean and SD of } \\
\text { PASE in men }\end{array}$ & $\begin{array}{c}\text { Mean and SD of PASE } \\
\text { in women }\end{array}$ & $\begin{array}{c}\text { p } \\
\text { value }\end{array}$ \\
\hline $\begin{array}{l}\text { Leisure-time physical } \\
\text { activities }\end{array}$ & $55.3 \pm 33.8$ & $49.1 \pm 31.9$ & $62.9 \pm 34.6$ & 0.001 \\
\hline $\begin{array}{l}\text { Housework physical } \\
\text { activities }\end{array}$ & $49.8 \pm 34.1$ & $46.1 \pm 34.5$ & $54.4 \pm 32.9$ & 0.001 \\
\hline $\begin{array}{l}\text { Job-related physical } \\
\text { activities }\end{array}$ & $8.85 \pm 34.8$ & $15 \pm 44.7$ & $1.1 \pm 11.2$ & 0.001 \\
\hline $\begin{array}{l}\text { Physical activities without } \\
\text { considering job }\end{array}$ & $105.2 \pm 53.3$ & $95.3 \pm 51.4$ & $117.4 \pm 53.1$ & 0.001 \\
\hline Total physical activities & $114.1 \pm 64.7$ & $110.3 \pm 71.1$ & $118.6 \pm 55.5$ & 0.035 \\
\hline
\end{tabular}

Table 3. Multiple variance analysis of bone mineral density and various factors affecting it based on mean and standard deviation

\begin{tabular}{|c|c|c|c|c|c|c|}
\hline \multicolumn{2}{|c|}{ Variable } & $\begin{array}{l}\text { Normal } \\
(N=221)\end{array}$ & $\begin{array}{c}\text { Osteopenia } \\
(\mathrm{N}=505)\end{array}$ & $\begin{array}{c}\text { Osteoporosis } \\
(\mathrm{N}=387) \\
\text { T-Score }<-2.5 \text { SD }\end{array}$ & Total & $\begin{array}{c}p \\
\text { value }\end{array}$ \\
\hline Age(year) & & $66.1 \pm 5.7$ & $68.1 \pm 6.9$ & $69.8 \pm 7.3$ & $68.3 \pm 6.9$ & 0.001 \\
\hline \multirow[b]{2}{*}{ Sex } & Male & $166(\% 75.2)$ & 350 (69.3) & 100 (\%25.8) & $\begin{array}{c}616 \\
(\% 55.3)\end{array}$ & \multirow{2}{*}{0.001} \\
\hline & Female & 55 (\%24.8) & 155 (\%30.6) & 287 (\%74.2) & $\begin{array}{c}497 \\
(\% 44.7) \\
\end{array}$ & \\
\hline BMI & & $29.4 \pm 3.9$ & $27 \pm 4.3$ & $26.4 \pm 4.9$ & $27.3 \pm 4.6$ & 0.001 \\
\hline \multirow{3}{*}{$\begin{array}{l}\text { Physical } \\
\text { activity }\end{array}$} & Leisure-time & $54.4 \pm 32.6$ & $53.3 \pm 33.1$ & $58.2 \pm 35.2$ & $55.3 \pm 33.8$ & 0.093 \\
\hline & Housework & $55.8 \pm 35.5$ & $48.6 \pm 34.4$ & $48.07 \pm 32.3$ & $49.8 \pm 34.1$ & 0.014 \\
\hline & Job-related & $12.01 \pm 41.2$ & $10.6 \pm 38.3$ & $4.72 \pm 24.1$ & $8.85 \pm 34.8$ & 0.013 \\
\hline
\end{tabular}

A significant positive correlation was observed between total physical activity and bone mineral density of the femur (Fig. 1), (for BMD.F ( $\mathrm{r}=0.101),(\mathrm{p}=0.001)$, and TF $(\mathrm{r}=0.119),(\mathrm{p}=0.001))$, but this relationship was insignificant in the lumbar spine (for BMD.S $(r=0.016), \quad(p=0.597)$ and TS $(r=0.008), \quad(p=0.779)), \quad$ although bone mineral density was increased in both areas and genders by increasing physical activity. 


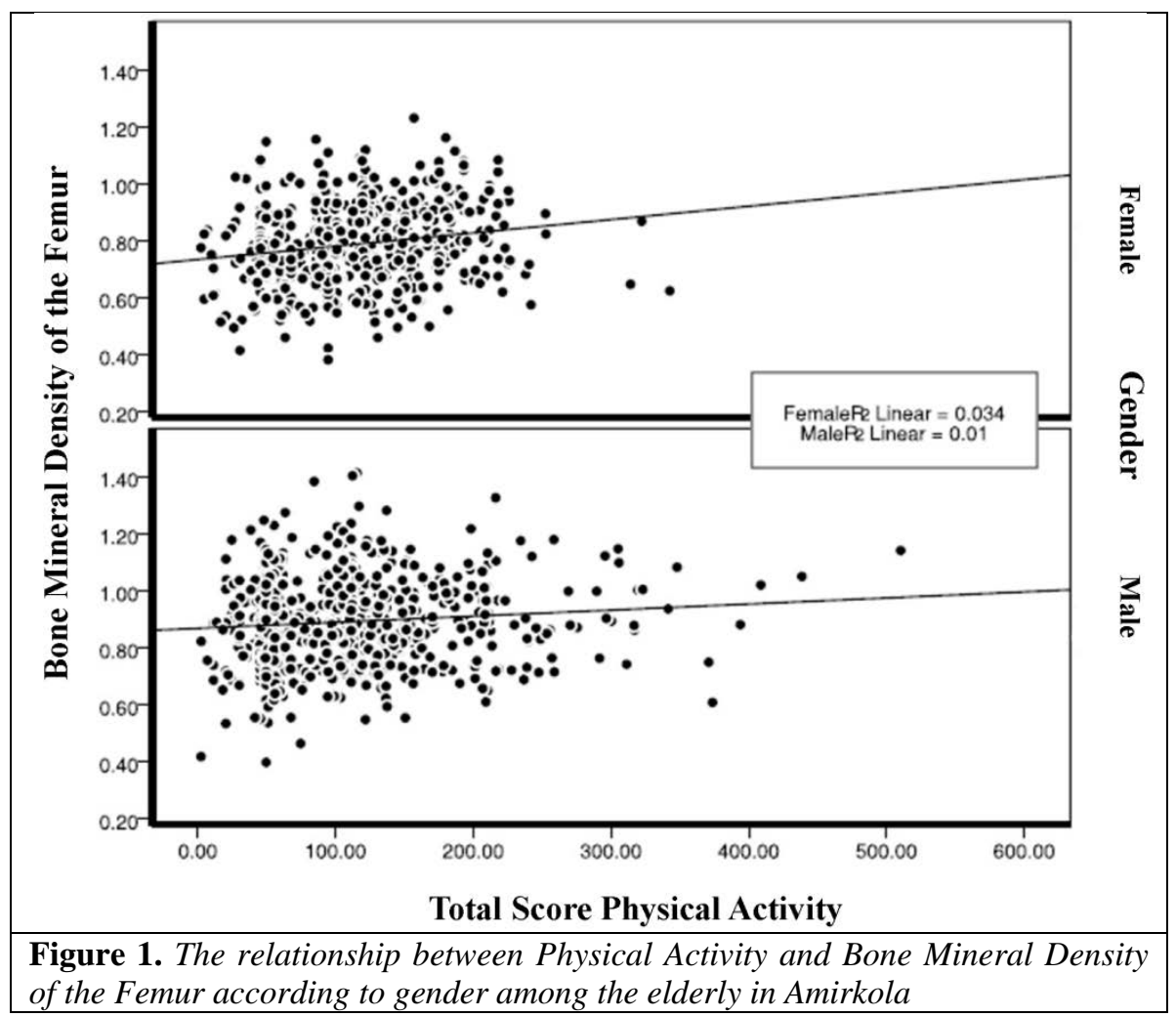

In the linear regression model, the variables of physical activity $(\mathrm{p}=0.05$, Beta $=0.055)$, age $(\mathrm{p} \leq 0.001$, Beta $=-0.234)$, and BMI $(p \leq 0.001, \quad B e t a=0.292)$ had significant relationships with bone mineral density in the femur, but vitamin $\mathrm{D}$ and calcium did not play a role. In addition, physical activity had no significant positive relationship with bone mineral density in the lumbar spine, but the reverse was true between age and bone mineral density in the lumbar area. The positive relationship between BMI and bone mineral density in this area was also significant. Notably, data analysis showed that patients with a history of bone fracture, randomly divided into each group, were homogenously distributed; thus, a history of bone fracture had no notable effects on the results of other variables.

\section{DISCUSSION}

Osteoporosis is the most common metabolic bone disease characterized by low bone mass and deterioration of bone tissue, which causes bone thinning and makes bone prone to fracture (2). The World Health Organization has determined osteoporosis to be the world's third leading health problem after heart disease and cancer (23). Perhaps determining the factors most influential on bone mineral density will help control this global problem.

In the current study, bone mineral density in the femur and lumbar areas was increased with an increase in physical activity in both genders; those with osteoporosis had less physical activity than those in other groups. Variables of physical activity, age, and BMI had significant associations with bone mineral density in the femur, but vitamin $\mathrm{D}$ played no role. In addition, physical activity and bone mineral density in the lumbar area 
had no significant positive correlation, but age and BMI had significant effects in this area. The mean bone mineral mass of both the lumbar and femur areas was higher in men than in women, and bone mineral mass increased when BMI was increased.

In their study on determining the risk factors for osteoporosis in women over 50, Sharami et al. (2008) identified significant associations between parameters including age (inverse association), education (positive association), career (positive association), physical activity (positive association), and BMI (positive association) and osteoporosis $(p \leq 0.05)$. They also reported a higher prevalence of osteoporosis in women who had a BMI of less than 25 (23). Employment, physical activity of more than 3 hours per week, and a BMI over 25 were identified as protective factors for osteoporosis (24). These findings correspond with the results of the current study. Almost all studies reported a negative relationship between age and BMD, which confirms the findings of the current study (25-27).

In this study, bone mineral density in the femur neck was significantly lower in lean subjects than in the obese. There was also a strong correlation between BMI and femur neck BMD. BMI was an independent predictive factor for femur neck BMD, but it had no association with lumbar spines (28). Fawzy et al. (2011) studied the relationship between body mass index and bone mineral density in patients aged 25 to 80 years and showed that the risk of low BMD was 50\% lower in overweight people compared with people with normal BMIs; this risk was $89 \%$ lower in obese individuals compared to normal-weighted individuals, which was statistically significant (28). Their study, in line with the current study, reported that a lower BMI was a risk factor for occurrence of low BMD (29).

Bener et al. (2005) recommended more than 30 minutes of daily walking to increase $\mathrm{BMD}$ of the spine and femur (24). In most studies, the positive effects of physical activity and mechanical pressure caused an increase in bone mineral density. Therefore, appropriate physical activity strengthens the bones and increases bone density (23). Researchers have found that bone mineral content in older women (50 to 73 years old) who exercised twice a week for 1 hour and 8 months in total increased $3.5 \%$, and in the low physical activity group, it decreased to $2.7 \%$. It seems that regular physical activity and resistance exercises have useful effects on bone loss associated with age (10). In an article by Farin et al. (2005) on the relationship between physical activity and bone mineral density in postmenopausal women, physical activity had a positive effect on bone density, and increased physical activity was recommended for these individuals (3). The findings of the current study correlated with the positive effects of physical activity on bone density in elderly women.

In their 2005 study on the long-term effects of resistance, speed, and strengthening activities on bone mineral density in male elite athletes, Salehikia et al. (2008) determined that the response of bones to mechanical load is dependent on the type and mode of exercise (29). Ala et al. (2010) and Vainionpää et al. (2006) showed in their assessments of exercise and osteoporosis in postmenopausal women that not all types of sports programs have a positive effect on bone density; type, severity, and duration of exercise movements are important factors in increasing bone mass $(30,31)$. It is also noted that weight-bearing exercises may not only delay bone loss, but can actually increase bone density in elderly men and women (15).

Ruchan (2011) reported in his article on the impact of physical activity on bone mineral density that women with high levels of physical activity have higher bone mineral density levels, indicating a direct association between the level of physical 
activity and bone mineral density (32). Hossein-nezhad et al. (2007) studied the relationship between bone mineral density and lifestyle in men and demonstrated that BMD was significantly associated with calcium, vitamin $\mathrm{D}$, physical activity, and smoking (33). Results of the current study, however, suggested no significant relationship between vitamin $\mathrm{D} /$ calcium and bone mineral density.

Farr et al. (2011) identified increased duration, frequency, and number of exercises as important stimuli for osteogenesis that should be considered in future interventions on physical activity (34). Other researchers found that intensive exercise had no effect on the BMD of elderly women, but it had a positive effect on bone mineral content (BMC) in the femur trochanter (35). Kemmler et al. (2010) identified an 18month exercise program effective on improving BMD and the risk of falling in elderly women (36).

The current study had some limitations. Many factors can affect bone mineral density, which are negligible because of the large sample size. Determining the amount of calcium in the diet of elderly people is problematic, because determining the exact amount of daily food intake of elderly people (the previous three days) is hindered by their memory problems, the intolerance of the elderly for long interviews, the large number of samples, and the large amount of time this determination required. Interviews and physical examinations of each individual took at least two hours, and the exact food status of the participants required even further time. It was not within the objectives of this study and required another survey. The disability of some of the elderly participants and the distance between BMD centers and Amirkala caused some individuals not to refer for the bone scan, which was another limitation of this study.

\section{CONCLUSION}

This study determined that increased levels of physical activity among the elderly of Amirkola decreased the risk of osteoporosis and decreased bone mineral density loss. According to these results, low intensity weight-bearing exercises in accordance with the principles of safety are recommended for the elderly. Moreover, the risk of osteoporosis is reduced in the elderly with a higher body mass index; therefore, having a normal body weight is recommended for the elderly.

\section{APPLICABLE REMARKS}

- It should be considered to do more exercise to prevent osteoporosis in the elderly.

- It is essential to maintain a normal body mass index in the elderly.

\section{ACKNOWLEDGEMENTS}

The authors wish to recognize and express appreciation to the Department of Research and Technology of Babol University of Medical Sciences for funding this project, the Health Deputy of the University for cooperating in this project, and the elderly of Amirkola for participating in this study.

\section{REFFRENCES}

1. Hosseini S, Gumming R, Sajjadi P, Bijani A. Chronic diseases among older people in Amirkola, northern Islamic Republic of Iran. Eastern Mediterranean Health Journal. 2011;17(11):843-9.

2. Bagheri P, Haghdoost AA, Dortaj Rabari E, Halimi L, Vafaei Z, Farhang Nya M, et al. Ultra Analysis of Prevalence of Osteoporosis in Iranian Women "A Systematic Review and Meta-analysis". Iranian Journal of Endocrinology and Metabolism. 2011;13(3):315-25 [Article in Farsi]. 
3. Farin N, Ostad Rahimi AR, Mahboub SA, Kolahi S, Ghavami SM. Survey of Relatioship between Physical Activity and Bone Mineral Density in Postmenopausal Women. Medical Journal of Tabriz University of Medical Sciences. 2008;30(1):79-83 [Article in Farsi].

4. Faulkner RA, Bailey DA. Osteoporosis: a pediatric concern? Medicine and sport science. 2007;51:1-12.

5. Burge R, Dawson-Hughes B, Solomon DH, Wong JB, King A, Tosteson A. Incidence and economic burden of osteoporosis-related fractures in the United States, 2005-2025. Journal of bone and mineral research : the official journal of the American Society for Bone and Mineral Research. 2007;22(3):465-75.

6. Carter ND, Kannus P, Khan KM. Exercise in the prevention of falls in older people: a systematic literature review examining the rationale and the evidence. Sports medicine (Auckland, NZ). 2001;31(6):427-38.

7. Chang JT, Morton SC, Rubenstein LZ, Mojica WA, Maglione M, Suttorp MJ, et al. Interventions for the prevention of falls in older adults: systematic review and meta-analysis of randomised clinical trials2004 $2004-$ 03-18 22:59:13. $680 \mathrm{p}$.

8. Seyedi L, Nikravesh B, Sarmadi AR. Osteoporosis (prevention, diagnosis and treatment). 1st ed: Sarmadi Pub; 2014. 168 [Book in Farsi] p.

9. Pazhouhi M, Komeylian Z, Sedaghat M, Baradar Jalili R, F. SAA, Ardeshir Larijani MB. Efficacy Of Educational Pamphlets For Improvement Of Knowledge And Practice In Patients With Osteoporosis. Payesh. 2004;3(1):67-74 [Article in Farsi].

10. Robergs RA, Roberts S. Fundamental Principles of Exercise Physiology: For Fitness, Performance, and Health: McGraw-Hill; 2000.

11. Wilmore JH, Costill DL, Kenney WL. Physiology of Sport and Exercise: Human Kinetics; 2008.

12. Hind K, Burrows M. Weight-bearing exercise and bone mineral accrual in children and adolescents: a review of controlled trials. Bone. 2007;40(1):14-27.

13. Karlsson M. Has exercise an antifracture efficacy in women? Scandinavian journal of medicine \& science in sports. 2004;14(1):2-15.

14. Lanyon LE. Functional strain as a determinant for bone remodeling. Calcified tissue international. 1984;36 Suppl 1:S56-61.

15. McArdle WD, Katch FI, Katch VL. Exercise Physiology: Nutrition, Energy, and Human Performance: Lippincott Williams \& Wilkins; 2010.

16. Hosseini SR, Cumming RG, Kheirkhah F, Nooreddini H, Baiani M, Mikaniki E, et al. Cohort profile: the Amirkola Health and Ageing Project (AHAP). International journal of epidemiology. 2014;43(5):1393-400.

17. Washburn RA, McAuley E, Katula J, Mihalko SL, Boileau RA. The physical activity scale for the elderly (PASE): evidence for validity. Journal of clinical epidemiology. 1999;52(7):643-51.

18. Washburn RA, Smith KW, Jette AM, Janney CA. The Physical Activity Scale for the Elderly (PASE): development and evaluation. Journal of clinical epidemiology. 1993;46(2):153-62.

19. Ishaghi R, Mahmoudian SA, Asgarian R, sohrabi A. Effect of Faith-based Education on Physical Activity on the Elderly. Iranian Journal of Medical Education. 2011;10(5):1281-8 [Article in Farsi].

20. Hosseini SR, Sajjadi P, Jamali S, Noreddini HG, Ghadimi R, Bijani A. The Relationship between Body Mass Index and Bone Mineral Density in Older People. Journal of Babol University Of Medical Sciences. 2014;16(7):14-22.

21. National Osteoporosis Foundation. Clinician’s Guide to Prevention and Treatment of Osteoporosis. Washington, DC: National Osteoporosis Foundation, 2010.

22. Bijeh N, Atarzadeh Hosseini SR, Hatef HR. The Comparison of Bone Mineral Density and Muscle Strength of Athletic and Non-Athletic Girls on Two Groups (Volleyball and Taekwondo). Iranian Journal of Basic Medical Sciences. 2006;9(2):83-90 [Article in Farsi].

23. Sharami SH, Millani F, Alizadeh A, Abbasi Ranjbar Z, Shakiba M, Mohammdi A. Risk factors of osteoporosis in women over 50 years of age: a population based study in the north of Iran. J Turkish-German Gynecol Assoc. 2008;9(1):38-44.

24. Bener A, Hammoudeh M, Zirie M, Heller RF. Is obesity a protective factor for osteoporosis? APLAR Journal of Rheumatology. 2005;8(1):32-8.

25. Larijani B, Hossein-Nezhad A, Mojtahedi A, Pajouhi M, Bastanhagh MH, Soltani A, et al. Normative data of bone Mineral Density in healthy population of Tehran, Iran: A Cross sectional study. BMC Musculoskeletal Disorders. 2005;6:38-.

26. Silva HG, Mendonca LM, Conceicao FL, Zahar SE, Farias ML. Influence of obesity on bone density in postmenopausal women. Arquivos brasileiros de endocrinologia e metabologia. 2007;51(6):943-9.

27. Toth E, Ferenc V, Meszaros S, Csupor E, Horvath C. Effects of body mass index on bone mineral density in men. Orvosi hetilap. 2005;146(28):1489-93.

Monemi, A. Amiri., and et al. (2015). Ann Appl Sport Sci, 3(2): 23-32. 
28. Fawzy T, Muttappallymyalil J, Sreedharan J, Ahmed A, Alshamsi SO, Al Ali MS, et al. Association between Body Mass Index and Bone Mineral Density in Patients Referred for Dual-Energy X-Ray Absorptiometry Scan in Ajman, UAE. Journal of osteoporosis. 2011;2011:876309.

29. Salehikia A, Khayambashi K, Marandi SM, Banparvari M. Effect of Longitudinal Endurance, Sprint and Strength Activity on Bone Mineral Density in Elite Male Athletes. Olympic. 2008;16(3):7-17 [Article in Farsi].

30. Aala M, Aghaei Meybodi H, Peymani M, Larijani B. Osteoporosis and Exercise in Postmenopausal Women. Iranian Journal of Endocrinology and Metabolism. 2010;11(2):209-17.

31. Vainionpaa A, Korpelainen R, Vihriala E, Rinta-Paavola A, Leppaluoto J, Jamsa T. Intensity of exercise is associated with bone density change in premenopausal women. Osteoporosis international : a journal established as result of cooperation between the European Foundation for Osteoporosis and the National Osteoporosis Foundation of the USA. 2006;17(3):455-63.

32. Ruchan I. The effect of physical activity on bone mineral density. International Journal of Physical Sciences. 2011;6(16):4097-101.

33. Hossein-nezhad A, Maghbooli Z, Bandarian F, Mortaz S, Soltani A, Larijani B. Association of Bone Mineral Density and Lifestyle in Men. Iranian Journal of Public Health. 2007;0(A supplementary issue):51-6.

34. Farr JN, Blew RM, Lee VR, Lohman TG, Going SB. Associations of physical activity duration, frequency, and load with volumetric BMD, geometry, and bone strength in young girls. Osteoporosis international : a journal established as result of cooperation between the European Foundation for Osteoporosis and the National Osteoporosis Foundation of the USA. 2011;22(5):1419-30.

35. Korpelainen R, Keinanen-Kiukaanniemi S, Heikkinen J, Vaananen K, Korpelainen J. Effect of impact exercise on bone mineral density in elderly women with low BMD: a population-based randomized controlled 30-month intervention. Osteoporosis international : a journal established as result of cooperation between the European Foundation for Osteoporosis and the National Osteoporosis Foundation of the USA. 2006;17(1):109-18.

36. Kemmler W, von Stengel S, Engelke K, Haberle L, Kalender WA. Exercise effects on bone mineral density, falls, coronary risk factors, and health care costs in older women: the randomized controlled senior fitness and prevention (SEFIP) study. Archives of internal medicine. 2010;170(2):179-85. 


\section{ارتباط بين تراكم مواد معدنى استخوان و سطح فعاليتبدنى سالمندان 'على منعمى اميرى، 'سيد رضا حسينى *، بفرهاد رحمانى نيا، ‘ُحاجى قربان نور الدينى، هلى بيزنى اهنى}

ا. كارشناس ارشد گروه تربيت بدنى و علوم ورزشى، دانشكاه آزاداسلامى، واحد علوم و تحقيقات گيلان، رشت، ايران.

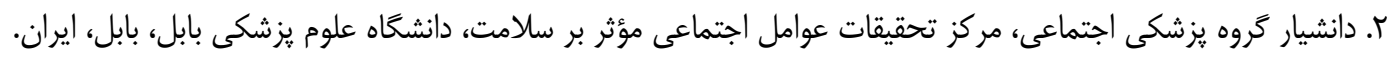

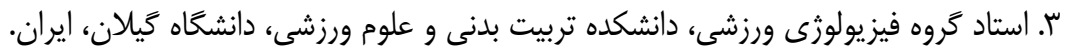

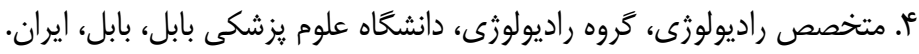

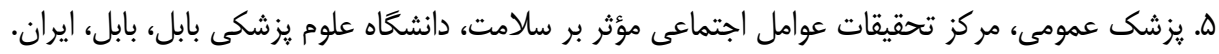

جکكيده

هدف از يزوهش حاضر، بررسى رابطه بين سطح فعاليتبدنى و تراكم مواد معدنى استخوان در سالمندان شهر اميركلا در شمال ايران بود. اين

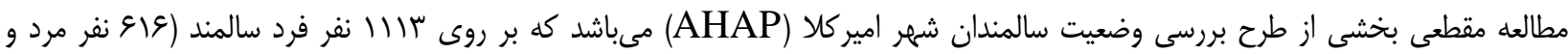

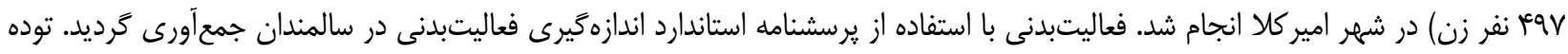

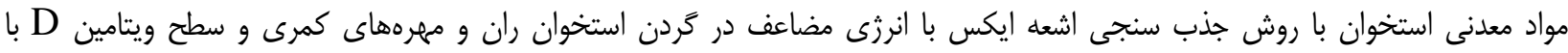

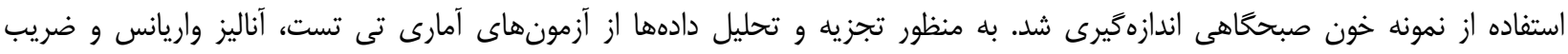

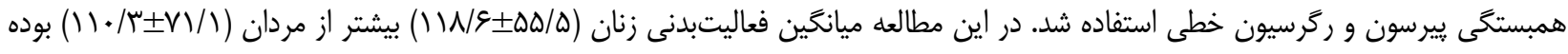

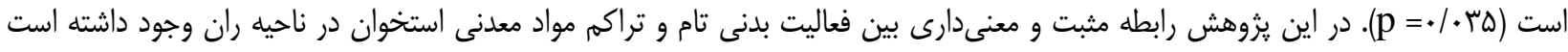

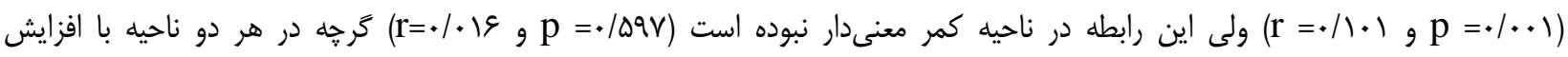

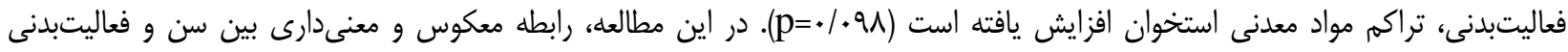

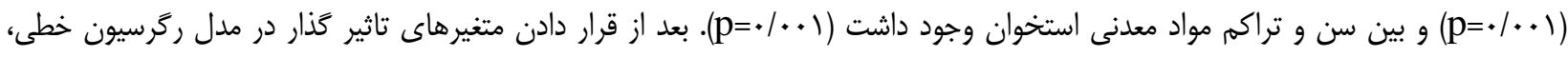

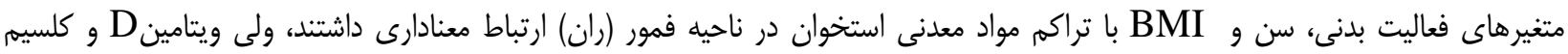

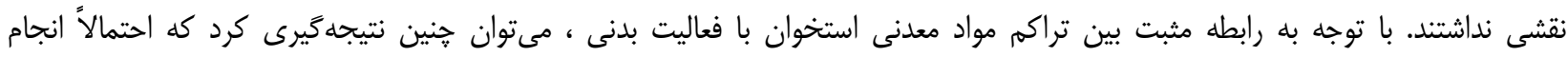

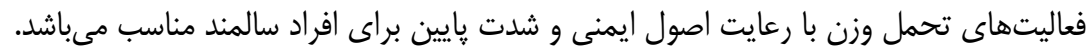

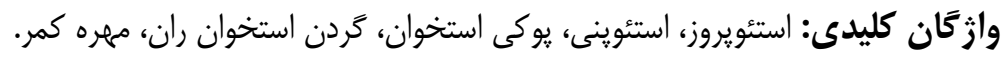

\section{* - نوسنده مسئول: \\ سيد رضا حسينى نئن}

hosseinim46@yahoo.com : بست الكترونيك حينى 